\title{
The relationship between position on an electoral list and chances of winning a seat in a representative body; experiences from the 2015 Sejm election in Poland
}

\begin{abstract}
This paper examines the relationship between the candidate's position on an electoral list and the feasibility of winning a seat in the Sejm (the lower chamber of the Polish parliament). This research hypothesizes that winning a seat strongly depends on the candidate having a top position on the electoral list. This hypothesis is verified vis-à-vis the results of the 2015 election to the Sejm. The study confirmed the initial assumption, since it was found that nearly $82 \%$ of the seats were taken by the candidates from the so-called "seat-winning places," namely the top places on the lists of candidates (the number of these places equals the number of seats taken by a given party in a given constituency).
\end{abstract}

Key words: Elections, electoral system, electoral formula, Polish Parliament, "seat-winning places"

\section{Introductory remarks}

$\mathbf{T}$ aking a synthetic approach to the issue of electoral systems (or electoral formulae), it can be demonstrated that modern elections to representative bodies employ either the majority formula, the proportional representation formula or a mixed one. The choice of formula has a considerable impact on the electoral strategies adopted by the candidates, as well as the election results and the allocation of seats in a given public authority. The issue studied in this paper is of utmost importance for political life, and is therefore both the subject of academic consideration and of discussions amongst the political elite and the public. Poland has witnessed a particularly lively debate on the electoral formula used in elections to the Sejm (the lower chamber of the Polish parliament). Since 1991, the formula of proportional representation has been used in elections to the Sejm, but virtually since the beginning of the political transformation in Poland, it has been suggested that a majority formula should be implemented in single-member constituencies. Its advocates argue that proportional representation vests excessive power in political parties, especially their leadership, because they make decisions about their respective electoral lists and by this token have a considerable impact on who will be elected to the Sejm. This results from the fact that candidates from top places on the lists are usually elected.

The purpose of this study is to discuss the issue of the influence that a candidate's place on the electoral list has on his or her chances of winning a seat in the Sejm. The research hypothesis posed at the beginning of this investigation assumed that winning a seat hinges on a high position on the electoral list. In order to verify this hypothesis, the results of the 2015 parliamentary elections were examined. 
The first stage of the investigation was carried out primarily by means of the analysis and critique of the sources. In the subsequent stages, the institutional-and-legal method, statistical methods and systemic analysis were employed. All of the statistics analyzed in the empirical study were obtained from the website of Polish National Electoral Commission (Wybory..., 2015).

The considerations in this paper are embedded in the concept of what is called "seat-winning places," defined as "all the top places on the list that correspond to the number of seats a given party won in a given constituency. If a party wins one seat in the constituency, only the first place on the list is a seat-winning one. If a party wins five seats, the 1-5 top places are seat-winning ones. By definition, there is a total of 460 seat-winning places amongst all the parties" (Flis, Opinia...). According to the concept presented by Flis, all places on the electoral lists can be categorized into two groups: seat-winning and non-seat-winning. The former are located at top of the list and correspond to the number of seats a given party won in a given constituency. This does not apply only to the first place on the list, because if a party wins a larger number of seats in the constituency, a larger number of places qualify as seat-winning ones. Non-seat-winning places are those located further down on the list. Importantly, if a given party fails to win a single seat, all the places on its electoral list will be qualified as non-seat-winning.

The beginning of this study presents the principles of the proportional representation electoral formula. This is followed by the analysis of the regulations in the Constitution of the Republic of Poland of 1997 and of the Act of January 5, 2011 - the Election Code, which pertain to elections to the Sejm. Both these sections of this paper focus on those aspects of the research topic that are significant for the methodological assumptions of this paper to be examined. The final part of the paper presents research results that serve as a basis for the verification of the research hypothesis.

\section{The formula of proportional representation - selected issues}

The term "electoral formula" can be defined as a "principle (or a set of principles) regulating which candidate is elected in a given constituency and how the number of votes garnered by a given party 'translates' into the number of seats that the party is allocated" (Antoszewski, 1997, p. 229). Thus, an electoral formula means a principle used to translate the number of votes cast for a given party into seats in the public authority being elected. The electoral formula is one of the elements of the electoral system (for more see: Antoszewski, 1997, pp. 228-230). Because of the topic of this paper, matters pertaining to the formula of proportional representation are discussed below.

Elections conducted under the formula of proportional representation are run in multi-member constituencies, so parties are obliged to present electoral lists of their candidates in each constituency. There are two ways to construct electoral lists, namely 'open' or 'closed' lists. 'In the open-list system, apart from indicating the list of a given political party, or a coalition of parties, voters select a specific candidate, thereby indicating their preferences for who should win the seat. In the closed-list system, the seats are allocated according to the order of candidates determined by those who drew up the list" 
(Krasnowolski, 2015, p. 11). The adoption of a given system of candidate lists leads to specific ramifications for both voters and candidates. Voters enjoy more power when the electoral procedure employs the open-list system because "apart from indicating specific parties, voters indicate their preferred candidates on respective lists" (Rachwał, 2017a, p. 70). Analyzing the places of candidates in the system of closed lists, it can be said that they are placed in a hierarchy in a way that cannot be changed by voters. The seats won by a given party are assigned to the candidates in the order of their places on the list, while in the system of open lists, the seats are assigned according to the number of votes garnered (this means that a candidate further down the list may win a seat, whereas a candidate from a top place may not).

In the second stage of determining the election results, the seats are assigned to the candidates from a given list. In the first stage, it is determined how many seats different parties have won. "The proportional representation system means that, firstly, the seats are divided between electoral lists, and it is only in the second stage that the candidates are allocated seats, according to the number of votes garnered (or the order of candidates on the list)" (Rachwał, 2017a, p. 67).

There are different methods used in the first stage of determining the election results (including the frequently applied methods of d'Hondt and Sainte-Laguë, as is the case in Poland). "Electoral commissions that apply the d'Hondt method divide the seats between different lists by dividing the number of valid votes received by every list [...] by $1,2,3,4$ and so on, until the quotients obtained yield a series of largest whole numbers that add up to the total number of seats to be divided among the lists [...]; every list is allocated as many seats as indicated by the largest successive numbers obtained by calculating the quotients as described above" (Polskie..., p. 225). The Sainte-Laguë method "employs an identical calculation, yet here the divisors are odd numbers" (Antoszewski, 1997, p. 235). The adopted method of seat division in the election has an impact on the composition of the body being elected (for more see: Rachwał, 2017a, pp. 67-70). The d'Hondt method favors larger parties more (as they win the largest number of seats with this method), whereas the Sainte-Laguë method is preferred mainly by small and medium-sized parties as it results in a more proportional division of seats (the winning party does not obtain a significant surplus of seats).

When analyzing the proportional electoral formula, it should be stressed that, in order for a party to participate in the division of seats, a minimum level of support from voters may be required. A barrage clause (or electoral threshold) is an "arbitrary threshold that a party is required to meet in order to participate in the division of seats" (Antoszewski, 1997, p. 230). This allows us to distinguish an introductory stage in which the election results are established by indicating which parties are able to take part in the division of seats. The threshold is typically established at the level of a few percent, preventing the smallest parties from being allocated seats.

The proportional representation formula is applied in multi-member constituencies where the parties present lists of their respective candidates. Depending on the method applied, voters either vote on a given list (in a closed-list system), or - as well as indicating the list - they may also indicate their preferred candidates (in an open-list system). Whether the party participates in the division of seats or not may depend on the level of voter support (usually set at a few percent). This is known as a "barrage clause" ("elec- 
toral threshold"). After the authorized parties are identified, the seats are divided, first between the lists, and then between the candidates from the respective lists (either according to their place on the list or the number of votes collected).

\section{Legislation regulating elections to the Sejm}

According to the Constitution of the Republic of Poland of 1997, "elections to the Sejm shall be universal, equal, direct and proportional and shall be conducted by secret ballot" (Konstytucja..., Art. 96.2). The legislator thus decided that elections to the Sejm should be conducted according to the proportional formula, which reflects the prevalent sentiments of the political forces which took part in shaping the new constitution. "The majority of participants in the debate on the constitution opted for the proportional formula to be adopted in elections to the Sejm, although the introduction of the majority formula was also suggested" (Rachwał, 2017b, p. 10). The latter option was mainly supported by the circles which submitted the draft of the constitution under the citizen's initiative. ${ }^{1}$ This draft opted for a solution whereby "at least two thirds of all deputies shall be elected in the majority election, with a proviso that an absolute majority of valid votes is required in the first round of voting" (quoted after: Chruściak, 2002, p. 50). If this wording of the regulation had been accepted, it would have meant that elections to the Sejm would be conducted according to a mixed method, or the majority method only. A representative of the supporters of this draft observed that "the Sejm is a more political chamber, where organized social groups should be represented. A minimum of two thirds of deputies are elected in the majority election. By this token, the deputies are closer to the nation, because the electorate knows individual people and can hold them responsible; in the long run this would also strengthen the parties, as they would rely on their social foundation" (quoted after: Chruściak, 2002, p. 54). This line of reasoning shows the conviction that, by way of the majority formula, the connection between political elites and the electorate would be stronger. "Ultimately, the National Assembly decided by an overwhelming majority to keep the proportional formula in elections to the Sejm" (Rachwał, 2017b, p. 11).

The constitutional regulations pertaining to elections to the Sejm, among other things, are further elaborated in the Act of January 5, 2011 - Election Code (Dz. U. [Journal of Laws] 2017, Item 15 as amended). Since elections to the Sejm are conducted according to the proportional formula, the territory of Poland is divided into 41 multi-member constituencies. "At least seven deputies shall be elected in every constituency. A constituency shall be equivalent to a region or its part" (Kodeks, Art. 201.2-3). The number of deputies elected in a constituency follows from the uniform standard of representation ${ }^{3}$

1 "A legislative initiative to present the draft of a new Constitution to the National Assembly is also vested in a group of citizens whose draft will receive the support of at least 500,000 people eligible to vote in elections to the Sejm" (Ustawa..., Art. 1.1).

2 "The division into constituencies, their number and borders as well as the number of deputies elected from each constituency and the location of district election commissions are determined in Annex no. 1 to the Code" (Kodeks, Art. 202.2).

3 "The number of deputies elected in particular constituencies and the division of regions into constituencies is established according to a uniform standard of representation, calculated by dividing 
applied, which is to ensure that elections are equal in material terms. "The material sense of equality means that every vote has the same power, that is, the influence of each vote on election results is identical" (Prawo..., p. 158).

Given the subject of this paper, the regulations on the division of seats in the Sejm are essential. Three main stages can be identified in this respect:

- parties with the right to partake in the division of seats in constituencies are identified;

- the numbers of deputies allocated to respective parties in constituencies are established;

- seats are allocated to candidates from the authorized electoral lists.

The division of seats in constituencies in the first stage is conducted only among the lists of those parties that have won voter support at the level determined by the threshold clause. By virtue of the Election Code, election thresholds have been established at the level of 5\% for parties and $8 \%$ for coalitions. "Parties established by voters associated in registered organizations of national minorities" may be exempted from the requirement to collect voter support at the level of 5\% (Kodeks, Art. 197.1).

In order to accomplish the second stage in the process of determining election results, the following provision of the Election Code is applied: "the district electoral commission divides the seats among the authorized lists in the following manner: (1) the number of valid votes cast on every such list in the constituency is successively divided by $1,2,3,4$ and so on, until the quotients obtained yield a series of the largest whole numbers that add up to the total number of seats to be divided among the lists in this constituency; (2) each list is allocated the number of seats determined by the number of successive largest whole numbers assigned to it out of the quotients calculated in the above-determined manner" (Kodeks, Art. 232.1). The number of deputies allocated to parties in a constituency is therefore established using the d'Hondt method. "The seats allocated to a given list are then allocated to the candidates from the list according to the number of votes collected by them" (Kodeks, Art. 233.1). Thus, seats are allocated to the candidates from the authorized parties on the basis of the number of votes each of them has won (open-list system).

In summary, elections to the Sejm are conducted according to the proportional representation formula, which results in multi-member constituencies. Additionally, seats available in the constituency may be allocated only to those parties which have received at least $5 \%$ or $8 \%$ of valid votes cast nationwide. In order to divide the seats between the lists, the d'Hondt method is used. After this stage in the division of seats is completed, it is determined which candidates from different lists will represent voters in the Sejm. Since the legislator adopted the system of open lists, the seats are allocated to the candidates who have received the largest number of votes.

the number of residents of Poland by the total number of deputies elected in constituencies" (Kodeks, Art. 202.1).

4 "Only lists of candidates for deputies of parties whose lists received at least $5 \%$ of valid votes cast in the country are included in the allocation of seats in electoral districts. The lists of candidates for deputies of coalitions are included in the allocation of seats in electoral districts, if their lists received at least $8 \%$ of valid votes cast in the country" (Kodeks, Art. 196). 


\section{The relationship between the place on an electoral list and winning a seat - experiences from the 2015 election to the Sejm}

Parties that took part in the 2015 election to the Sejm collected a total of 460 seats (which follows from the relevant regulation in the Constitution of the Republic of Poland of $\left.1997^{5}\right)$; 377 of them were allocated to the candidates from "seat-winning places," whereas the other 83 went to candidates from the remaining places on electoral lists. This means that nearly $82 \%$ of the representatives of the nation were elected from "seatwinning places" and a little over 18\% from "non-seat-winning places." Table 1 below presents detailed statistics.

The number of deputies elected on the basis of their place on the list

\begin{tabular}{|l|c|c|c||}
\hline \multicolumn{1}{|c|}{ Party } & $\begin{array}{c}\text { Number of deputies } \\
\text { elected from "seat- } \\
\text { winning places" }\end{array}$ & $\begin{array}{c}\text { Number of deputies } \\
\text { elected from "non- } \\
\text { seat-winning places" }\end{array}$ & $\begin{array}{c}\text { Total number of depu- } \\
\text { ties from the party }\end{array}$ \\
\hline Law and Justice Party (PiS) & 188 & 47 & 235 \\
\hline Civic Platform Party (PO) & 105 & 33 & 138 \\
\hline "Kukiz' 15" Movement & 40 & 2 & 28 \\
\hline $\begin{array}{l}\text { Nowoczesna Ryszarda Petru } \\
\text { (Modern Party) }\end{array}$ & 28 & 0 & 16 \\
\hline Polish Peasants' Party (PSL) & 15 & 1 & 1 \\
\hline German Minority Party & 1 & 0 & 460 \\
\hline Total & $\begin{array}{c}377 \\
(81.96 \% \text { of seats })\end{array}$ & 83 & $(18.04 \%$ of seats $)$ \\
\hline
\end{tabular}

Source: Author's elaboration based on the statistics of National Electoral Commission: Wybory do Sejmu i Senatu Rzeczypospolitej Polskiej 2015, parlament2015.pkw.gov.p1/349_Wyniki_Sejm, 21-22.02.2018.

Analysis of the statistics presented in Table 1 shows that a larger number of deputies from "non-seat-winning places" were elected from the lists of the largest parties, whereas the deputies from smaller parties entered Sejm almost exclusively from "seatwinning places." In the case of the Law and Justice party, 47 deputies were elected from "non-seat-winning places," and in the case of the Civic Platform party - 33 deputies, which accounts for $20 \%$ and $23.9 \%$ of seats won by the given party respectively. The four smaller parties ("Kukiz' 15," Modern Party, Polish Peasants' Party and German Minority) won a total of 87 seats, $84(96.55 \%)$ of which were taken by the candidates from "seat-winning places" and only 3 (3.45\%) from "non-seat-winning places."

Therefore, candidates running for the seats in the Polish Sejm from lower places on the lists stand a chance of being elected, especially if they represent the largest parties (nevertheless, the earlier observation should be borne in mind that a definite majority of seats are won by the candidates from top places on electoral lists, even in the case of the largest parties). The experience of the 2015 election also shows that candidates from smaller parties, which won the support of just a small percentage of voters, in principle stand a chance of being elected only provided that they are in top positions on their lists (provided that their respective parties meet the preliminary condition of overcoming

\footnotetext{
5 "The Sejm is made of 460 deputies" (Konstytucja..., Art. 96.1).
} 
the threshold). Out of the 87 seats that were won by the representatives of the abovementioned "smaller parties," as many as 80 were obtained by the candidates from top places on their respective lists.

The results of this research also show that the last place on the list is a good option for candidates from "non-seat-winning places." For instance, the candidates from the Polish Peasants' Party won 16 seats in the election examined - 15 from top places and 1 from the last place on the list. A total of 13 candidates from the last place on their list won seats. Given that 83 deputies were elected from "non-seat-winning places," this is quite a high proportion (candidates from the last place on their lists won $15.66 \%$ seats won by those from "non-seat-winning places").

Table 2 presents the research question, taking into account Poland's division into constituencies.

Table 2

The number of deputies elected on the basis of their place on the list taking into account the number of constituencies in Poland

\begin{tabular}{|c|c|c|c|}
\hline $\begin{array}{l}\text { Constituency } \\
\text { number }\end{array}$ & $\begin{array}{l}\text { Number of deputies } \\
\text { elected from } \\
\text { "seat-winning places" }\end{array}$ & 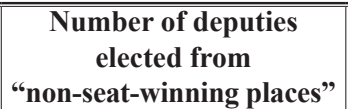 & $\begin{array}{c}\text { Total number of deputies } \\
\text { elected } \\
\text { in the constituency }\end{array}$ \\
\hline 1 & 2 & 3 & 4 \\
\hline 1 & 9 & 3 & 12 \\
\hline 2 & 6 & 2 & 8 \\
\hline 3 & 12 & 2 & 14 \\
\hline 4 & 11 & 1 & 12 \\
\hline 5 & 10 & 3 & 13 \\
\hline 6 & 14 & 1 & 15 \\
\hline 7 & 10 & 2 & 12 \\
\hline 8 & 10 & 2 & 12 \\
\hline 9 & 9 & 1 & 10 \\
\hline 10 & 8 & 1 & 9 \\
\hline 11 & 10 & 2 & 12 \\
\hline 12 & 6 & 2 & 8 \\
\hline 13 & 10 & 4 & 14 \\
\hline 14 & 9 & 1 & 10 \\
\hline 15 & 7 & 2 & 9 \\
\hline 16 & 10 & 0 & 10 \\
\hline 17 & 8 & 1 & 9 \\
\hline 18 & 11 & 1 & 12 \\
\hline 19 & 15 & 5 & 20 \\
\hline 20 & 9 & 3 & 12 \\
\hline 21 & 10 & 2 & 12 \\
\hline 22 & 9 & 2 & 11 \\
\hline 23 & 13 & 2 & 15 \\
\hline 24 & 13 & 1 & 14 \\
\hline 25 & 8 & 4 & 12 \\
\hline 26 & 11 & 3 & 14 \\
\hline 27 & 7 & 2 & 9 \\
\hline 28 & 6 & 1 & 7 \\
\hline 29 & 7 & 2 & 9 \\
\hline
\end{tabular}




\begin{tabular}{|c|r|r|r||}
\hline 1 & 2 & 3 & 4 \\
\hline 30 & 8 & 1 & 9 \\
\hline 31 & 10 & 2 & 12 \\
\hline 32 & 8 & 1 & 9 \\
\hline 33 & 11 & 5 & 8 \\
\hline 34 & 7 & 1 & 10 \\
\hline 35 & 9 & 1 & 12 \\
\hline 36 & 10 & 2 & 9 \\
\hline 37 & 7 & 2 & 10 \\
\hline 38 & 7 & 2 & 8 \\
\hline 39 & 7 & 3 & 12 \\
\hline 40 & 6 & 2 & 460 \\
\hline 41 & 9 & 3 & 83 \\
\hline Total & 377 & & \\
\hline
\end{tabular}

Source: Author's elaboration based on the statistics of National Electoral Commission: Wybory do Sejmu i Senatu Rzeczypospolitej Polskiej 2015, parlament2015.pkw.gov.pl/349_Wyniki_Sejm, 21-22.02.2018.

For elections to the Sejm, Poland's territory is divided into 41 constituencies, where citizens elect between 7 and 20 deputies. As indicated in Table 2, the number of candidates elected in individual constituencies from "non-seat-winning places" was usually one (13 constituencies) or two (17 constituencies). Not a single deputy was elected from non-seat-winning places in one constituency, while three deputies from non-seat-winning places were elected in six constituencies, four in two constituencies, and five in two constituencies. Candidates running in these elections can be divided into two general categories. One comprises the candidates from top positions on the lists who therefore stand a considerable chance of being elected. The other one is made up of candidates in lower places on the lists, whose chances of successfully winning a seat are considerably smaller. The members of the latter group work for the results of their respective lists in order for their party to be allocated the largest number of seats in their constituency in the first stage of determining the election results. The study shows that other candidates may also win a seat in the Sejm, but this holds true for the representatives of the largest parties first and foremost.

\section{Conclusions}

Designing the methodological assumptions for this paper, the research hypothesis was that winning a seat in the Sejm is to a large extent dependent on the candidate holding a top position on the electoral list. The analysis carried out confirmed this hypothesis. On the basis of the 2015 election to the Sejm, it was established that nearly $82 \%$ of seats were taken by candidates from seat-wining places. Therefore, it was demonstrated that there is a strong relationship between the candidate's position on the list and his or her chance of winning a seat. A lower position on the list (a non-seat-winning place) by no means rules out the candidate's chances of winning a seat, and this is especially feasible when running from the lists of the parties which enjoy the greatest voter support. As far as non-seat-winning places are concerned, the analysis showed that the candidates running from the last place on the list won a seat relatively frequently. 


\section{Bibliography}

Antoszewski A. (1997), contributed by R. Alberski, Systemy wyborcze, in: Demokracje zachodnioeuropejskie. Analiza porównawcza, eds. A. Antoszewski, R. Herbut, Wrocław.

Chruściak R. (2002), Sejm i Senat w Konstytucji RP z 1997 r. Powstawanie przepisów, Warszawa.

Flis J., Opinia o wprowadzeniu parytetu ptci na listach kandydatów (Druk nr 2713), Opinie Biura Analiz Sejmowych, http://orka.sejm.gov.pl/rexdomk6.nsf/Opdodr?OpenPage\&nr=2713, 19.02.2018.

Kodeks = Ustawa z dnia 5 stycznia 2011 roku - Kodeks wyborczy, Dz. U. 2017, poz. 15, z późn. zm.

Konstytucja Rzeczypospolitej Polskiej z dnia 2 kwietnia 1997 r., Dz. U. 1997, Nr 78, poz. 483, z późn. $\mathrm{zm}$.

Krasnowolski A. (2015), Procedury wyborcze w krajach europejskich, OT-635, Kancelaria Senatu, Warszawa, http://www.senat.gov.pl/gfx/senat/pl/senatopracowania/130/plik/ot-635_do_internetu.pdf, 20.02.2018.

Polskie prawo konstytucyjne (2000), ed. W. Skrzydło, Lublin.

Prawo konstytucyjne (2000), ed. Z. Witkowski, Toruń.

Rachwał M. (2017a), Wybory we wspótczesnym państwie demokratycznym, in: Uwarunkowania i mechanizmy partycypacji politycznej, ed. M. Rachwał, Poznań.

Rachwał M. (2017b), Evolution of the System of Elections to the Polish Sejm - the Matter of Election Formula, "Przegląd Politologiczny," no. 1.

Website of the National Electoral Commission: Wybory do Sejmu i Senatu Rzeczypospolitej Polskiej 2015, parlament2015.pkw.gov.pl/349_Wyniki_Sejm, 21-22.02.2018.

Ustawa z dnia 22 kwietnia 1994 r. o zmianie ustawy konstytucyjnej o trybie przygotowania i uchwalenia Konstytucji Rzeczypospolitej Polskiej, Dz. U. 1994, Nr 61, poz. 251.

\section{Miejsce na liście wyborczej a uzyskanie mandatu w organie przedstawicielskim. Doświadczenia wyborów do Sejmu RP z 2015 roku}

\section{Streszczenie}

Zagadnieniem badawczym przybliżonym w niniejszym artykule jest kwestia zależności między miejscem zajmowanym przez kandydata na liście wyborczej a możliwością uzyskania mandatu w Sejmie RP. Hipotezą badawczą było założenie, iż uzyskanie mandatu posła jest w znacznej mierze uzależnione od zajmowania miejsca na początku listy wyborczej. Weryfikacja przyjętej hipotezy nastapiła na podstawie wyników wyborów do Sejmu RP z 2015 roku. Przeprowadzone badania potwierdziły słuszność wyjściowego założenia, gdyż okazało się, iż niemal 82\% mandatów zdobyły osoby z „miejsc mandatowych", a zatem z miejsc otwierających listy kandydatów (liczba tych miejsc jest równa liczbie mandatów zdobytych przez komitet w danym okręgu wyborczym).

Słowa kluczowe: wybory, system wyborczy, formuła wyborcza, Sejm RP, „miejsca mandatowe” 
